\title{
Prosomatostatin-derived Antrin Is Present in Gastric D Cells and in Portal Blood
}

M. Ravazzola,* R. Benoit, ${ }^{*}$ N. Ling, ${ }^{*}$ and L. Orci*

*Institut d'Histologie et d'Embryologie, 1211 Genève 4, Switzerland; ${ }^{\ddagger}$ Department of Medicine, Montreal General Hospital, McGill

University, Montreal H3G 1A4, Canada; and ${ }^{\S}$ Laboratories for Neuroendocrinology, The Salk Institute, La Jolla, California 92037

\begin{abstract}
The three widely distributed peptides derived from prosomatostatin are the original neurohormone somatostatin-14, somatostatin-28, and somatostatin-28(1-12), which are all derived from the $\mathrm{COOH}$ terminus of the precursor. Recently a decapeptide derived from the $\mathrm{NH}_{2}$ terminus of the prohormone has been identified in extracts of rat gastric antrum and named antrin. Data now show that in both rats and humans this new molecular form is concentrated in the $D$ cell of the gastrointestinal mucosa together with somatostatin-28(1-12). The highest concentration of antrin immunofluorescent cells is located in the mucosa of the gastric antrum. Ultrastructural studies performed on pyloric D cells using the protein A-gold technique reveals that antrin is present in the same secretory granules as somatostatin-28(1-12) and detectable in one-third of all secretory granules. Acid extracts of rat hepatic portal plasma contain a peptide similar or identical to antrin, indicating that the antral decapeptide circulates in blood.
\end{abstract}

\section{Introduction}

The notion that peptide hormones are derived from precursor proteins by posttranslational modification is now well recognized (1). During the maturation process several peptides may be generated together with the hormone. These other peptides, often called cryptic peptides, are important for three reasons: (a) their presence provides information on the processing events, $(b)$ some are better markers for a given peptidergic system than the hormone itself, and $(c)$ among these peptides, a few could serve a biological role. After a new molecular form has been identified in a given tissue extract, several questions are raised, such as whether it may represent an artifact of extraction. If the peptide is not produced artifactually it is important to know the cell type from which it originates and whether it can be secreted by these cells.

Somatostatin is a bioactive peptide of 14 or 28 amino acids that generally acts as a paninhibitor in the neuroendocrine system. It is derived from the $\mathrm{COOH}$-terminal end of a $10-\mathrm{kD}$ precursor protein, prosomatostatin (2-5) (Fig. 1). We have

Address correspondence to Dr. M. Ravazzola, Département de Morphologie, Institut d'Histologie et d'Embryologie, Centre Médical Universitaire, 1, rue Michel-Servet, 1211 Genève 4, Switzerland.

Received for publication 23 May 1988 and in revised form 2 September 1988 .

J. Clin. Invest.

(c) The American Society for Clinical Investigation, Inc.

$0021-9738 / 89 / 02 / 0362 / 05 \$ 2.00$

Volume 83, February 1989, 362-366 recently isolated a peptide from rat stomach that corresponds to the first $\mathbf{1 0}$ amino acids at the $\mathrm{NH}_{2}$ terminus of mammalian prosomatostatin (6). In the rat, the highest concentration of the decapeptide is present in the gastric antrum, hence the proposed name antrin. It is presently assumed that antrin is formed after cleavage at a monobasic site very similar to that leading to formation of somatostatin-28 and somatostatin$28(1-12)$. In the present work we provide the first immunocytochemical data on the cellular and ultrastructural localization of antrin and compare it with somatostatin-28(1-12), an excellent marker of the prosomatostatin system in tissue $(7,8)$. Evidence is also presented for the antral decapeptide circulating in hepatic portal blood in rats.

\section{Methods}

\section{Antisera}

To obtain specific antibodies that recognize only antrin, not prosomatostatin or any of the other prosomatostatin-derived peptides, one must direct the formation of gamma globulin toward the $\mathrm{COOH}$ terminus of antrin. This was achieved by immunizing rabbits with a mixture of synthetic antrin and methylated BSA or with the analogue [TYR ${ }^{3}$ ]antrin (3-10) coupled to BSA as described previously for several other peptides (9). The immuno plasma generated by the first method (Fig. 2) was selected for immunocytochemical studies (A09). An antibody population with higher affinity (A14) was obtained by the second method and it was selected for quantitation of antrin by RIA. A previously characterized antibody population (S320) against somatostatin-28(1-12) was used as a marker of the prosomatostatin system (7).

\section{Immunocytochemistry}

Light microscopy. Pieces of pancreas and gastrointestinal mucosa of normal adult Sprague-Dawley rats fixed by vascular perfusion with $1 \%$ glutaraldehyde were dehydrated and embedded in Epon. Consecutive semithin sections $(1 \mu \mathrm{m})$ attached on glass slides were incubated by the indirect immunofluorescence method (10). Sections were treated to remove Epon (11) and then incubated for $2 \mathrm{~h}$ at room temperature with the primary antisera A09 (diluted 1:1,000) for antrin or S320 (diluted 1:4,000) for somatostatin-28(1-12) immunoreactivity. Sections were washed with PBS and then exposed to FITC-conjugated goat anti-rabbit IgG for $1 \mathrm{~h}$. After washing and counterstaining with 0.03\% Evans Blue the sections were examined with a fluorescence microscope (Axiophot; Carl Zeiss, Inc., Oberkochen, FRG). The procedure for the fixation and embedding of the human fetal tissue is detailed in reference 12 . Sections were etched with $5 \%$ (vol/vol) $\mathrm{H}_{2} \mathrm{O}_{2}$ before immunofluorescence labeling. Control of specificity was carried out by applying anti-antrin serum previously absorbed with $10 \mu \mathrm{g} / \mathrm{ml}$ antrin, prosomatostatin(1-32), somatostatin-14, somatostatin-28, or somatostatin-28(1-12).

Electron microscopy. Thin sections attached on nickel grids were immunostained by the protein A-gold (pAg) ${ }^{1}$ technique (13) with anti-

1. Abbreviations used in this paper: $\mathrm{pAg}$, protein A-gold. 


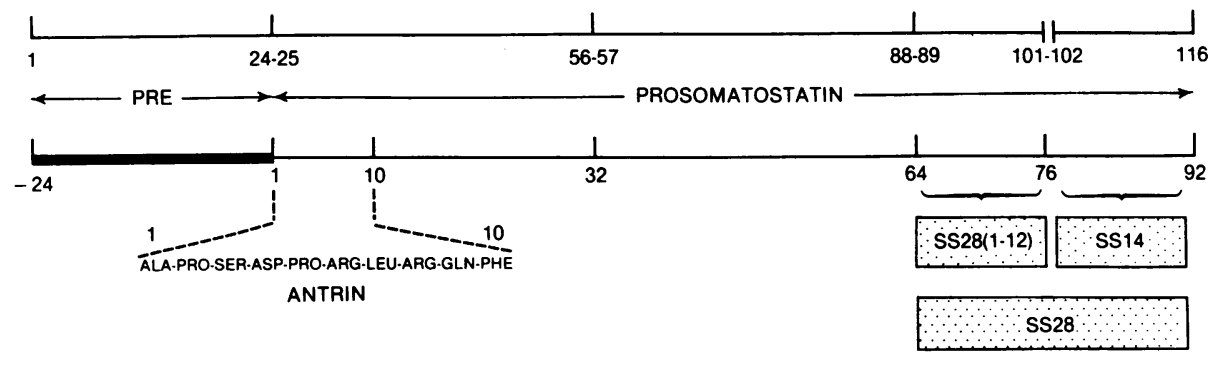

Figure 1. Schematic representation of the 116-amino acid precursor of mammalian somatostatin. It contains a signal peptide or "pre" region of 24 amino acids preceding the 92 amino acid prosomatostatin of $10 \mathrm{kD}$. Antrin represents the first 10 amino acids at the amino terminus of prosomatostatin while somatostatin-14 represents the last 14 amino acids at the carboxyl terminus. Direct and indirect evidence indicates that cleavage occurs at $\mathrm{Gly}^{24}$ $\mathrm{Ala}^{25}$, $\mathrm{Leu}^{56}-\mathrm{Leu}^{57}, \mathrm{Arg}^{88}-\mathrm{Ser}^{89}$, and $\mathrm{Arg}^{101}$-Lys $^{102}$. Antrin is probably generated through cleavage at $\mathrm{Lys}^{37}-\mathrm{Ser}^{38}$ (not shown), a monobasic site also present in catfish as $\mathrm{Arg}^{37}-\mathrm{Ser}^{38}$. antrin diluted 1:3,000 or anti-somatostatin diluted 1:4,000. Gold particles $10 \mathrm{~nm}$ in diameter were used. After immunolabeling sections were double stained with uranyl acetate and lead citrate and examined in an electron microscope (model 301; Philips Electron Optics, Eindhoven, The Netherlands).

The number of secretory granules expressing antrin immunoreactivity was quantified on photographic prints of 8-10 D cells (magnification of 34,000). 500-600 secretory granules were evaluated. Secretory granules showing at least four gold particles were counted as immunoreactive for antrin.

\section{Gel permeation chromatography of hepatic portal plasma}

Rat hepatic portal plasma was extracted with $2 \mathrm{M}$ acetic acid, the extract was loaded onto octadecylsilylsilica cartridges and the retentate eluted with acetonitrile. The material eluted with acetonitrile was dried, dissolved in 5.2 M acetic acid, and loaded onto a Sephadex G-75 gel permeation chromotography column. Each column fraction was monitored for the presence of antrin using an RIA in which iodinated $\left[T_{Y} R^{3}\right]$ antrin $(3-10)$ was used as the ligand.

\section{Results}

Immunofluorescence with A09 anti-antrin serum on sections of pancreas and gastrointestinal mucosa of rat revealed that antrin immunofluorescence was undetectable in pancreatic islets, seldom present in epithelial cells of oxyntic and duodenal mucosa, but clearly represented in endocrine cells of the gastric antrum (Fig. $3 \mathrm{~A}$ ). All antrin immunofluorescent cells examined reacted also with $\mathrm{S} 320$ antibody. The staining for antrin was more sparse than that for somatostatin-28(1-12) which, when present, produced a diffuse cytoplasmic staining (compare Fig. 3, $A$ and $B$ ). The same experiments performed in human fetal gastric tissue yielded similar results for both antrin and somatostatin-28(1-12) immunostaining (Fig. 3, C and $D$ ). Control of specificity showed that among the peptides used to adsorb the anti-antrin serum before the immunolabeling, only antrin abolished the staining.

At the ultrastructural level antrin immunoreactivity, local-

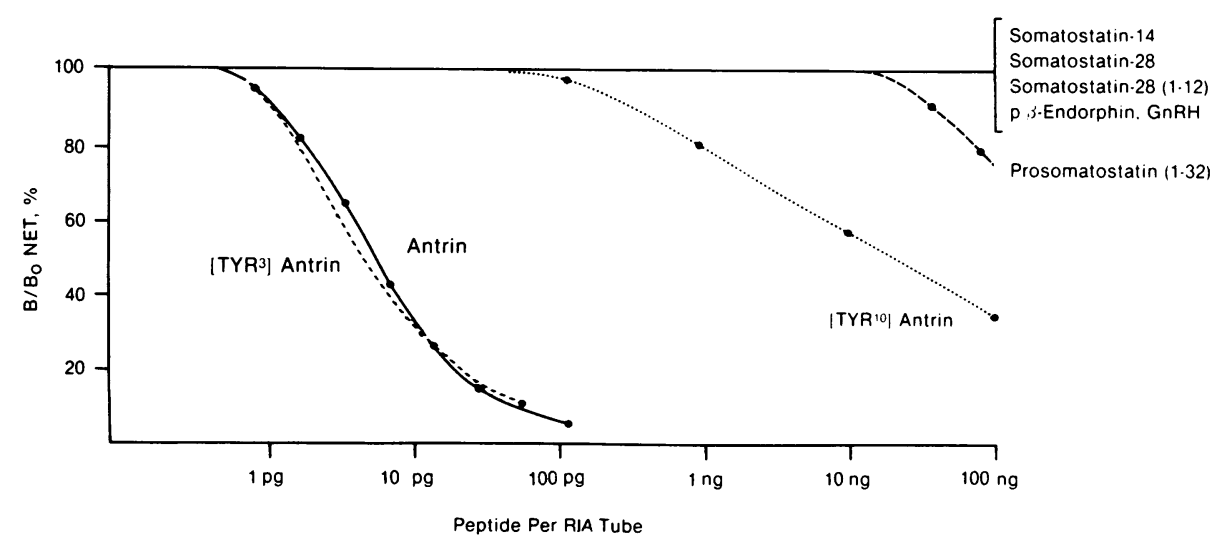

Figure 2. Characteristics of A09, an antibody population produced against antrin. A New Zealand White rabbit was immunized with an emulsion containing synthẹtic antrin (14), methylated BSA, and complete Freund adjuvant supplemented with $10 \mathrm{mg}$ killed mycobacterium tuberculosis as previously described (9). Booster injections were done with the same emulsion but without bacteria. $10 \mathrm{~d}$ after the second boost the immune plasma was collected and used at a $1 / 100,000$ dilution for RIA. The ligand was ${ }^{125}$ [ [TYR $\left.{ }^{3}\right]-$ antrin(3-10) which was obtained after iodination of $2.5 \mu \mathrm{g}\left[\mathrm{TYR}^{3}\right]$ antrin(3-

10) with $20 \mu \mathrm{g}$ chloramine $\mathrm{T}$ during $38 \mathrm{~s}$ followed by addition of $75 \mu \mathrm{g}$ sodium metabisulfite and $1 \mathrm{mg}$ human serum albumin. The label was purified on carboxymethyl cellulose (CM 52; Whatman Laboratory Products, Inc., Clifton, NJ) using 0.04 M ammonium acetate, pH 4.6, as the elution buffer. Net binding of label to antibody was $31 \%$ after $44 \mathrm{~h}$ incubation at $4^{\circ} \mathrm{C}$ in RIA buffer (9). The specificity studies represented here show that cross-reactivity with preproSS(25-33)-TYR (i.e., [TYR ${ }^{10}$ ]antrin) and prosomatostatin(1-32) is $0.03 \%$ and $0.003 \%$, respectively, indicating that $\mathrm{A} 09$ recognizes the $\mathrm{COOH}$-terminal region of antrin. This was confirmed by incubating ${ }^{125} \mathrm{I}-\left[\mathrm{TYYR}^{10}\right]$ antrin with A09 diluted at $1 / 10,000$. No binding was observed (data not shown). 

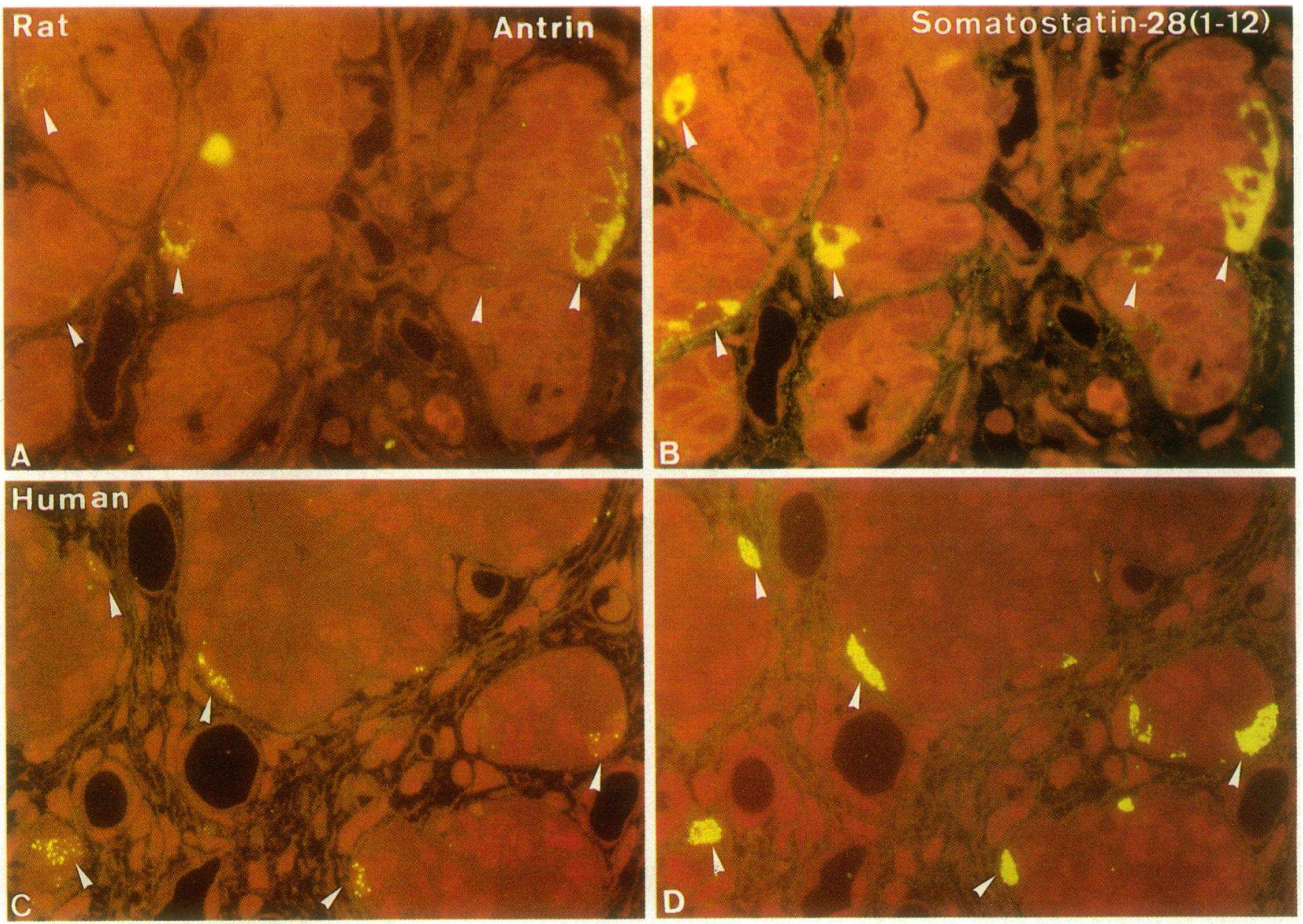

Figure 3. Localization of antrin and somatostatin-28(1-12) immunoreactivity by immunofluorescence on consecutive semithin sections of antral mucosa from adult rat $(A, B)$ and 17-wk human fetus $(C, D)$. The same $\mathrm{D}$ cells (arrowheads) show antrin and somatostatin-28(1-12) immunoreactivity. However, the pattern of antrin immunolabeling of individual cells appears rather sparse compared with the very bright and compact immunofluorescence of somatostatin-28(1-12). A, B: $\times 800 ; C, D: \times 630$.

ized by pAg, was observed over the secretory granules. Labeled granules frequently coexisted with granules devoid of immunolabeling (Fig. 4, $A$ and $C$ ). Quantitative evaluation of antrin-positive granules showed that they represented $33 \%$ of the population of secretory granules in rat D cells and $15 \%$ in human fetal D cells.

Comparing serial sections, one incubated with anti-antrin and the other with anti-somatostatin-28(1-12), it was found that the secretory granules containing antrin also contained somatostatin-28(1-12) (Fig. 4, $A-D$ ). By contrast, many somatostatin-positive granules do not contain antrin. Inasmuch as the antiserum recognizes the $\mathrm{COOH}$ terminus of prosomatostatin 1-10 (antrin) it appears that the processing of prosomatostatin to antrin occurs in only a subpopulation of the granules that process prosomatostatin to prosomatostatin28(1-12). Antrin could be a late cleavage product, occurring only in "old" granules, and never be secreted. When extract of rat hepatic portal plasma was subjected to gel permeation chromatography, it was found that a single peak of immunoreactivity eluted in a zone compatible with a peptide the size of antrin $(\sim 1,200 \mathrm{~mol} \mathrm{wt})$ (Fig. 5).

\section{Discussion}

The findings obtained with a specific antibody population directed toward antrin indicate $(a)$ that the decapeptide is present in secretory granules that also contain somatostatin$28(1-12)$, and $(b)$ that it is detectable in only a fraction of somatostatin-containing granules in a subpopulation of somatostatin-producing cells. This suggests differential precursor processing or product stability within the granules, and antrin could thus be a marker for the presence of specific cleavage enzymes.

Antrin cannot be detected by immunohistochemistry in gastric nerves, nor can it be detected in the $D$ cells of the pancreas. This restricted tissue distribution, namely that the endocrine cells of the stomach are the predominant site of antrin accumulation, suggests that the measurement of antrin in blood may represent a means by which to evaluate specifically the response of the gastric $\mathrm{D}$ cell during digestion. Together with the demonstration of this peptide in the portal circulation, it also suggests that antrin acts as a hormone during digestion. The high degree of amino acid sequence conser- 

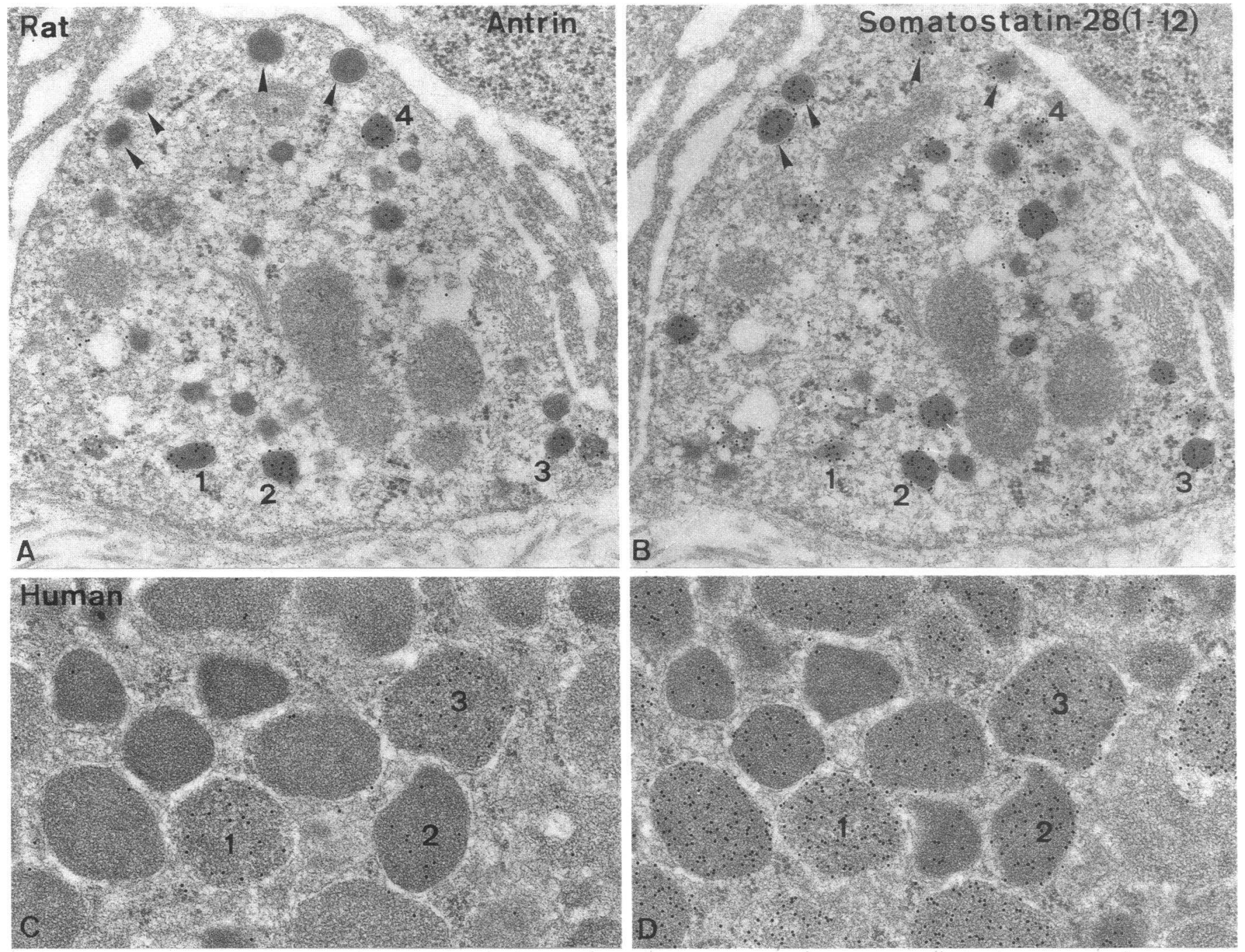

Figure 4. Localization of antrin and somatostatin-28(1-12) at the ultrastructural level on consecutive thin sections of antral D cells of rat $(A, B)$ and human fetus $(C, D)$ processed by the $\mathrm{pAg}$ method. In electron microscopy antrin was revealed over a population (33\% in rat, $15 \%$ in human) of secretory granules while somatostatin-28(1-12) was present on virtually all the secretory granules. Serially cut secretory granules containing antrin and somatostatin-28(1-12) immunoreactivity are numbered. Arrowheads point to secretory granules with somatostatin-28(112) but not antrin immunolabeling. $A, B: \times 34,000 ; C, D: \times 40,000$.

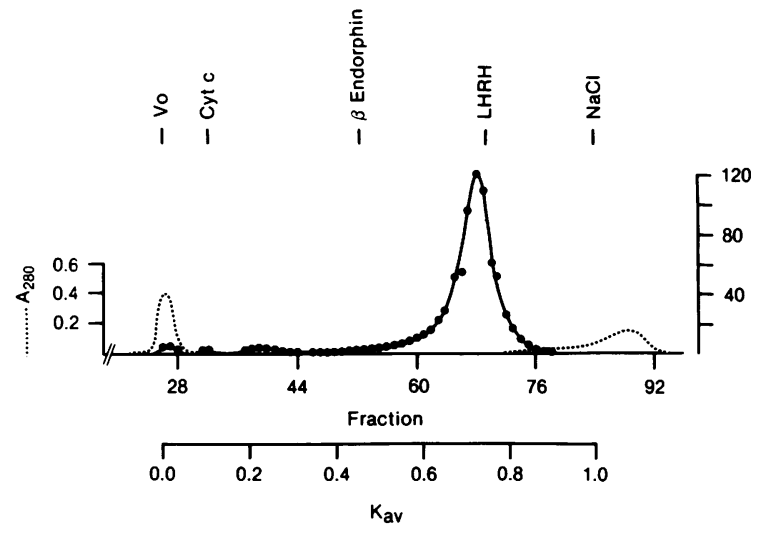

Figure 5. Sephadex G-75 gel permeation chromatography of an acid extract of $78 \mathrm{ml}$ rat portal plasma. Hepatic portal blood was collected in cold heparinized syringes from adult Sprague-Dawley rats fed ad lib. After centrifugation at $12,800 \mathrm{~g}$ for $2 \mathrm{~min}$ at $4^{\circ} \mathrm{C}$ the plasma was added to $2 \mathrm{M}$ acetic acid ( 1 vol. for 1 vol.), vortexed, frozen in liquid nitrogen, and kept at $-20^{\circ} \mathrm{C}$ until purification on Sep-Paks (Waters Associates, Milford, MA). The material eluted from octadecylsilylsilica cartridges with $80 \%$ acetonitrile in $0.1 \%$ trifluoroacetic acid was lyophilized. The dry powder was dissolved in 5.2 M acetic acid and loaded onto a Sephadex G-75 column $(2.6 \times 107 \mathrm{~cm})$. Antrin radioimmunoactivity was measured with antibody A14 in fractions 23-92. A major peak of immunoreactive material was detected at $0.7 K_{\mathrm{av}}\left[\left(V_{\mathrm{x}}-V_{0}\right) /\left(V_{\text {salt }}-V_{0}\right)\right]$, which is compatible with a peptide of $1,200-1,300 \mathrm{~mol} w \mathrm{wt}$. The column was previously calibrated with cytochrome $c, 12,384 \mathrm{~mol} \mathrm{wt}$, human $\beta$-endorphin, $3,466 \mathrm{~mol} \mathrm{wt}$, luteinizing-hormone releasing hormone (LHRH), $1,182 \mathrm{~mol} \mathrm{wt}$, and $\mathrm{NaCl}$, $58.5 \mathrm{~mol}$ wt. The peak seen in the void volume represents crystalline BSA (Pentex; Miles Laboratories, Inc., Elkhart, IN) 67,000 mol wt, used for coating the column. Flow rate was $21 \mathrm{ml} / \mathrm{h}$ and fraction size was $7 \mathrm{ml}$. 
vation from catfish to man in the region of prosomatostatin corresponding to antrin argues in favor of a biological role for that molecule (5).

\section{Acknowledgments}

We thank Dr. J.-D. Vassalli for critical reading of the manuscript, Ms. Gina Gravel, A.-M. Lucini, G. Moussard, and G. Perrelet for technical assistance, Mr. G. Negro and P.-A. Rüttimann for photographic work, and Ms. I. Bernard for typing.

This work was supported by the Swiss National Science Foundation (grant 3.404.86), The Medical Research Council of Canada (grant MA 9145), and The National Institutes of Health (grants HD-09690 and DK-18811).

\section{References}

1. Douglass, J., O. Civelli, and E. Herbert. 1984. Polyprotein gene expression: generation of diversity of neuroendocrine peptides. Annu. Rev. Biochem. 53:665-715.

2. Brazeau, P., W. Vale, R. Burgus, N. Ling, M. Butcher, J. Rivier, and R. Guillemin. 1973. Hypothalamic peptide that inhibits the secretion of immunoreactive pituitary growth hormone. Science (Wash. DC). 179:77-79.

3. Pradayrol, L., H. Jörnvall; V. Mutt, and A. Ribet. 1980. N-terminally extended somatostatin: the primary structure of somatostatin-28. FEBS (Fed. Eur. Biochem. Soc.) Lett. 109:55-58.

4. Benoit, R., P. Böhlen, N. Ling, A. Briskin, F. Esch, P. Brazeau, S.-Y. Ying, and R. Guillemin. 1982. Presence of somatostatin-28-(112) in hypothalamus and pancreas. Proc. Natl. Acad. Sci. USA. 79:917-921.
5. Argos, P., W. L. Taylor, C. D. Minth, and J. E. Dixon. 1983. Nucleotide and aminoacid sequence comparison of preprosomatostatins. J. Biol. Chem. 258:8788-8793.

6. Benoit, R., N. Ling, and F. Esch. 1987. A new prosomatostatinderived peptide reveals a pattern for prohormone cleavage at monobasic sites. Science (Wash. DC). 238:1126-1129.

7. Ravazzola, M., R. Benoit, R. Guillemin, and L. Orci. 1983. Immunocytochemical localization of prosomatostatin fragments in maturing and mature secretory granules of pancreatic and gastrointestinal D-cells. Proc. Natl. Acad. Sci. USA. 80:215-218.

8. Morrison, J. H., R. Benoit, P. J. Magistretti, and F. E. Bloom. 1983. Immunohistochemical distribution of prosomatostatin related peptides in cerebral cortex. Brain Res. 262:344-351.

9. Benoit, R., N. Ling, P. Brazeau, S. Lavielle, and R. Guillemin. 1987. Strategies for antibody production and radioimmunoassays. In Neuromethods: Peptides. Vol. 6. A. A. Boulton, G. B. Baker, and Q. J. Pittman, editors. Humana Press, Clifton, NJ. 43-72.

10. Coons, A. H., E. H. Leduc, and J. M. Connolly. 1955. Studies on antibody production. I. A method for the histochemical demonstration of specific antibody and its application to a study of the hyperimmune rabbit. J. Exp. Med. 102:49-63.

11. Maxwell, M. H. 1978. Two rapid and simple methods used for the removal of resin from $1.0 \mu \mathrm{m}$ thick epoxy sections. J. Microsc. (Lond.). 112:253-255.

12. Like, A. A., and L. Orci. 1972. Embryogenesis of the human pancreatic islets: a light and electron microscopic study. Diabetes. 21(Suppl. 2):511-534.

13. Roth, J., M. Bendayan, and L. Orci. 1978. Ultrastructural localization of intracellular antigens by the use of protein A-gold complex. J. Histochem. Cytochem. 26:1074-1081.

14. Ling, N., F. Esch, D. Davis, M. Mercado, M. Regno, P. Böhlen, P. Brazeau, and R. Guillemin. 1980. Solid phase synthesis of somatostatin-28. Biochem. Biophys. Res. Commun. 95:945-951. 